\title{
HOW RELIGIOUS ARE AMERICAN WOMEN AND MEN? GENDER DIFFERENCES AND SIMILARITIES
}

\author{
Landon Schnabel ${ }^{1}$ \\ Indiana University, Bloomington
}

\begin{abstract}
Are women universally more religious than men? Some research on gender differences has argued that biology leads women to be innately more religious than men, but other research has highlighted the importance of avoiding universal claims and recognizing complexity. This brief note uses General Social Survey data to report gender differences in predicted religiosity by religious category across eight measures. In the United States, gender differences seem to be primarily a Christian phenomenon. While women reveal higher levels of religiosity across Christian groups, this trend does not extend to non-Christian groups. Furthermore, there is variation even among Christian groups, with women not revealing higher levels of religiosity for all measures. Nevertheless, there does seem to be a general trend for women to report daily prayer more often than men. These findings further problematize the idea that there are innate gender differences in religiosity rooted in biology, and provide a descriptive foundation for future attempts to explain why (American) Christian groups reveal gender differences in religiosity.
\end{abstract}

This study has been published as: Schnabel, Landon. 2015. "How Religious Are American Women and Men? Gender Differences and Similarities." Journal for the Scientific Study of Religion 54(3):616-622. DOI: 10.1111/jssr.12214

\footnotetext{
${ }^{1}$ Direct correspondence to Landon Schnabel, Department of Sociology, Indiana University, 744 Ballantine Hall, 1020 E. Kirkwood Ave., Bloomington, IN 47405. Email: 1pschnab @indiana.edu.
} 
Some research on "universal" gender differences in religiosity has argued that biology leads women to be innately more religious than men (Miller and Stark 2002; Stark 2002). Although gender differences in religiosity are a consistent finding, more recent studies have highlighted the importance of avoiding universal claims and recognizing complexity (e.g., Cornwall 2009; Hastings and Lindsay 2013; Roth and Kroll 2007; Schnabel 2016; Sullins 2006).

Gender differences are not the same across measures, cultures, or religions (Freese and Montgomery 2007; Freese 2004; Sullins 2006). Sullins (2006) found that gender differences in religiosity vary by country and religious affiliation, and that some aspects of religiosity in non-Christian religions - such as Judaism and Islamappear to reveal a gender gap in the opposite direction. When considering anything to do with gender-including differences in religiosity - it is important to focus on particular societies and consider variance across groups within those societies (Collins 2000; Cornwall 2009).

In the United States, Christianity predominates and trends among Christian groups will seem to be society-wide because of the higher proportion of Christians in nationally-representative data. The Steensland et al. (2000) religious categorization scheme (RELTRAD), however, provides seven useful categories for comparing American religious groups: Black Protestant, evangelical Protestant, mainline Protestant, Catholic, Jewish, "other faith," and no affiliation. When first presenting their now standard religious categorization method, Steensland et al. (2000) empirically demonstrated that their recategorization of General Social Survey denominations predicts a number of religious and political outcomes with less bias than other methods, such as those that place Christians along a fundamentalism scale. ${ }^{1}$
More recently, the authors of the original study have argued that despite challenges, this categorization scheme still provides the best currently available categorization of American religious groups (Woodberry et al. 2012). Roth and Kroll (2007) compared gender differences within these categories across those who do and those who do not believe in an afterlife. They found that gender differences were most prominent among Christian groups. $^{2}$

Building on Roth and Kroll (2007), I use more recent data-which provide additional comparable measures - and a new method-predicted probabilities, which makes the magnitudes of differences more readily comparable across measures-to extend their findings. In this brief note, I use cross-sectional data from the 1994-2012 General Social Survey to report gender differences in religiosity and religious belief within religious category across eight measures. I handle missing data with listwise deletion.

This note reports predicted probabilities based upon multivariate logistic regression models including sociodemographic controls. By using predicted probabilities based upon logistic regressions (in which I fully interact all controls with gender), holding controls at gender and religion-specific local means, and using SPost 13 functions developed for Stata 13 by Long and Freese, I am able to arrive at precise and comparable outcomes for considering particular gender differences in religiosity (Long and Freese 2014; Long 2009). See the note beneath table 1 for what controls are included and Schnabel (2016) for a description of the dependent variables and more information on the methods used.

Because I hold controls at local means, the predicted probabilities can be interpreted as the actual percentage for a group. So, for example, a .58 for Black Protestant women being strongly affiliated 
can be generally interpreted as meaning that $58 \%$ of Black Protestant women identify as strongly affiliated with their religion. The results, then, provide not only a chance to compare how gender differences vary by religious categories, but they also supply a broad overview of American religiosity. ${ }^{3}$

\section{Results}

Figure 1 shows that Protestant religions are disproportionately comprised of women $\left(X^{2} \mathrm{p}\right.$ $<.001)$, whereas Catholics are similar to the Jewish category in being gender balanced $\left(X^{2}\right.$ not significant). Most of those in the "other religion" category or with no religious affiliation are men $\left(X^{2} \mathrm{p}<.001\right)$. Table 1 demonstrates that, among Christian groups and the unaffiliated, women are in general more religious than men. This pattern, however, does not extend to non-Christian groups in the United States, such as those in the Jewish and the "other religion" categories. "Universal" gender differences seem to be a largely Christian phenomenon.

[Figure 1 about here] [Table 1 about here]

Even among Christian groups, there is variation across measures. Among Black Protestants and evangelical Protestants, women are not more likely to believe in an afterlife than men. Similarly, Black Protestant women are not more likely to have tried to proselytize than Black Protestant men. Furthermore, mainline Protestant and Catholic women are not more likely to have had a "born again" experience than men. If a researcher hopes to find universal gender differences among women and men across U.S. religious groups, I suggest they focus solely on prayer and drop those in the "other religion" category. Women are significantly more likely to report daily prayer than men in all but the "other religion" category $(\mathrm{p}<.001$ for all but Jewish category; $\mathrm{p}<.01$ for the
Jewish category). ${ }^{4}$ Christian women generally reveal higher levels of religiosity than Christian men, but this trend varies across measures and type of Christian.

These results are generally consistent with Roth and Kroll's (2007) findings, but reveal more for the questions at hand about differences across groups (rather than across those who do or do not believe in an afterlife, which was Roth and Kroll's focus). Similar to what Roth and Kroll (2007) found, nonChristian groups do not reveal the same patterns of gender differences in religiosity as Christian groups. But different from Roth and Kroll's findings, this study presents the actual levels of religiosity for women and men across groups rather than just tests of whether gender differences are significant. Therefore, beyond confirming previous findings, this note provides two new contributions: (1) results based upon newer data that include additional religion measures, and (2) results based upon a method that provides a broad descriptive overview of American religiosity.

\section{Discussion}

Previous research has shown that gender differences do not extend to some nonChristian contexts worldwide (Sullins 2006). By comparing Christians and non-Christians in the United States, this note examined whether gender differences in religiosity are "universal" in the United States, or whether they just seem to be so because the U.S. is predominantly Christian.

"Universal" gender differences seem to be a primarily Christian phenomenon. American women are generally more religious than men, but this does not extend to non-Christian groups. Furthermore, there is variation even among Christian groups, with women not revealing higher levels of religiosity for all measures. Nevertheless, there does seem to be a general trend for American women to report daily prayer more often than men. 
The persistence of a gender difference-prayer-across most groups provides an opportunity to consider how consistent differences could be influenced by socialization, structural location, or other social explanations rather than biology (Cornwall 2009; Eagly and Wood 1999). For example, prayer frequency differences could arise because girls and boys are socialized differently from birth; boys are typically socialized to be more active and impulsive, whereas girls are socialized to be more reflective and communicative (Bem 1983; Eagly 1987). Alternatively, structural location explanations might suggest that prayer is a way for people whose agency is structurally limited to exert agency (Avishai 2008; Burke 2012) or that prayer provides a sense of security to people who are more existentially insecure (Norris and Inglehart 2011). The notion that gender differences are not innate or rooted in biology (Bem 1983; Eagly and Wood 1999; Hyde 2005) has long been discussed in much greater depth outside the more recent, and more limited, discussion in the sociology of religion (Cornwall 2009; Hoffmann 2009). Previous research on gender differences shows that it should not be surprising if groups of people that society

\section{Notes}

${ }^{1}$ A particularly helpful reviewer who was not certain that the Steensland et al. (2000) scheme improves on the Roof and McKinney (1987) scheme conducted their own analyses and noted that gender differences also vary by the Roof and McKinney categories. S/he said that her/his own analysis with the Roof and McKinney (1987) scheme "broadly confirms" my results and suggested that I note that my "findings are robust and do not depend on the RELTRAD categorization."

${ }^{2}$ I follow Roth and Kroll (2007) in not combining Mormons and Jehovah's sees, and treats, as inherently different appear, for non-biological reasons, to have some persistent differences (Glenn 2000; West and Fenstermaker 1995).

This note provides insight and implications for both the study of religion and gender. It supplies a readily accessible overview of the levels of religiosity expressed by both women and men in American religious groups. It also shows where gender differences do and do not exist, reaffirming studies (Sullins 2006) that highlight complexity rather than universality in gender differences. The findings further problematize the idea that there are innate gender differences in religiosity rooted in biology. Women are typically, but not universally, more religious than men. Finally, this note provides a descriptive foundation for future attempts to explain why (American) Christian groups reveal gender differences in religiosity. Future research that takes an intersectional approach may prove particularly revealing. I suspect that researchers may find that "universal" gender differences in religiosity vary not only by religious group as this note demonstrated, but also by race, income, and other factors.

Witnesses with Muslims, Hindus, and Buddhists in the "other faith" RELTRAD category. Instead of combining them with evangelicals as Roth and Kroll did, I drop Mormons and Jehovah's Witnesses so as to not compromise RELTRAD's carefully developed categorization of Protestants. Furthermore, I do not include any observations that are listed as either Protestant or Orthodox Christian in the GSS religious preference measure that the RELTRAD scheme places in the "other faith" category. I am left, therefore, with an "other religion" category that does not include Christians or those in groups closely related to Christianity. 
${ }^{3}$ This overview provides a basic resource that scholars not specifically interested in gender differences in religiosity could reference for levels of American religiosity by both gender and religious group.

${ }^{4}$ Sensitivity analyses holding means at religion-specific (rather than religion- and gender-specific) means, as well as analyses using global means, reveal substantively similar results, with a couple of notable changes for differences that were previously near significance thresholds. Religionspecific means were almost exactly the same as the religion- and gender-specific means, but there are a few differences when moving from local to global means. The Christian groups reveal substantively equivalent patterns, though Black Protestants reveal some differences due to the high correlation of this category with race (which is a large part of why local means are important). The only noteworthy changes among Jews and those in the "other religion" category when using global means vs. local means are that the higher likelihood of Jewish men being literalists is significant with global means and the higher likelihood for women to pray daily in the "other religion" category is also significant with global means. 


\section{References}

Avishai, Orit. 2008. "'Doing Religion' in a Secular World: Women in Conservative Religions and the Question of Agency." Gender \& Society 22(4):409-33.

Bem, Sandra Lipsitz. 1983. "Gender Schema Theory and Its Implications for Child Development: Raising Gender-Aschematic Children in a Gender-Schematic Society." Signs 8(4):598-616.

Burke, Kelsy C. 2012. "Women's Agency in Gender-Traditional Religions: A Review of Four Approaches." Sociology Compass 6(2):122-33.

Collins, Patricia Hill. 2000. Black Feminist Thought: Knowledge, Consciousness and the Politics of Empowerment. New York: Routledge.

Cornwall, Marie. 2009. "Reifying Sex Difference Isn't the Answer: Gendering Processes, Risk, and Religiosity." Journal for the Scientific Study of Religion 48(2):252-55.

Eagly, Alice H. 1987. Sex Differences in Social Behavior: A Social-Role Interpretation. Hillsdale, NJ: Lawrence Erlbaum Associates.

Eagly, Alice H. and Wendy Wood. 1999. "The Origins of Sex Differences in Human Behavior: Evolved Dispositions Versus Social Roles.” American Psychologist 54(6):408-23.

Freese, Jeremy. 2004. "Risk Preferences and Gender Differences in Religiousness: Evidence from the World Values Survey." Review of Religious Research 46(1):88-91.

Freese, Jeremy and James D. Montgomery. 2007. "The Devil Made Her Do It? Evaluating Risk Preference as an Explanation of Sex Differences in Religiousness.” Pp. 187-230 in Advances in Group Processes: The Social Psychology of Gender, edited by Shelley J. Correll. Oxford: Elsevier.

Glenn, Evelyn Nakano. 2000. "The Social Construction and Institutionalization of Gender and Race: An Integrative Framework.” Pp. 3-43 in Revisioning Gender, edited by Myra Marx Ferree, Judith Lorber, and Beth B. Hess. Walnut Creek, CA: AltaMira.

Hastings, Orestes P. and D. Michael Lindsay. 2013. "Rethinking Religious Gender Differences: The Case of Elite Women." Sociology of Religion 74(4):471-95.

Hoffmann, John P. 2009. "Gender, Risk, and Religiousness: Can Power Control Provide the Theory?" Journal for the Scientific Study of Religion 48(2):232-40.

Hyde, Janet Shibley. 2005. "The Gender Similarities Hypothesis." The American Psychologist 60(6):581-92.

Long, J. Scott. 2009. Group Comparisons in Logit and Probit Using Predicted Probabilities. Department of Sociology, Indiana University. Unpublished Manuscript.

Long, J. Scott and Jeremy Freese. 2014. Regression Models for Categorical Dependent Variables in Stata. 3rd ed. College Station, TX: Stata Press.

Miller, Alan S. and Rodney Stark. 2002. "Gender and Religiousness: Can Socialization Explanations Be Saved?” American Journal of Sociology 107(6):1399-1423.

Norris, Pippa and Ronald Inglehart. 2011. Sacred and Secular: Religion and Politics Worldwide. 2nd ed. New York: Cambridge University Press.

Roof, Wade Clark and William McKinney. 1987. American Mainline Religion: Its Changing Shape and Future. New Brunswick, NJ: Rutgers University Press.

Roth, Louise Marie and Jeffrey C. Kroll. 2007. "Risky Business: Assessing Risk Preference Explanations for Gender Differences in Religiosity." American Sociological Review 72(2):205-20.

Schnabel, Landon. 2016. "The Gender Pray Gap: Wage Labor and the Religiosity of HighEarning Women and Men.” Gender \& Society 30(4):643-69. 
Stark, Rodney. 2002. "Physiology and Faith: Addressing the 'Universal' Gender Difference in Religious Commitment." Journal for the Scientific Study of Religion 41(3):495-507.

Steensland, Brian et al. 2000. "The Measure of American Religion: Toward Improving the State of the Art." Social Forces 79(1):291-318.

Sullins, D. Paul. 2006. "Gender and Religion: Deconstructing Universality, Constructing Complexity." American Journal of Sociology 112(3):838-80.

West, Candace and Sarah Fenstermaker. 1995. "Doing Difference." Gender \& Society 9(1):8-37.

Woodberry, Robert D., Jerry Z. Park, Lyman A. Kellstedt, Mark D. Regnerus, and Brian Steensland. 2012. "The Measure of American Religious Traditions: Theoretical and Measurement Considerations." Social Forces 91(1):65-73. 


\section{FIGURES AND TABLES}

Figure 1: Percent Women and Men of Total Adherents in American Religious Categories

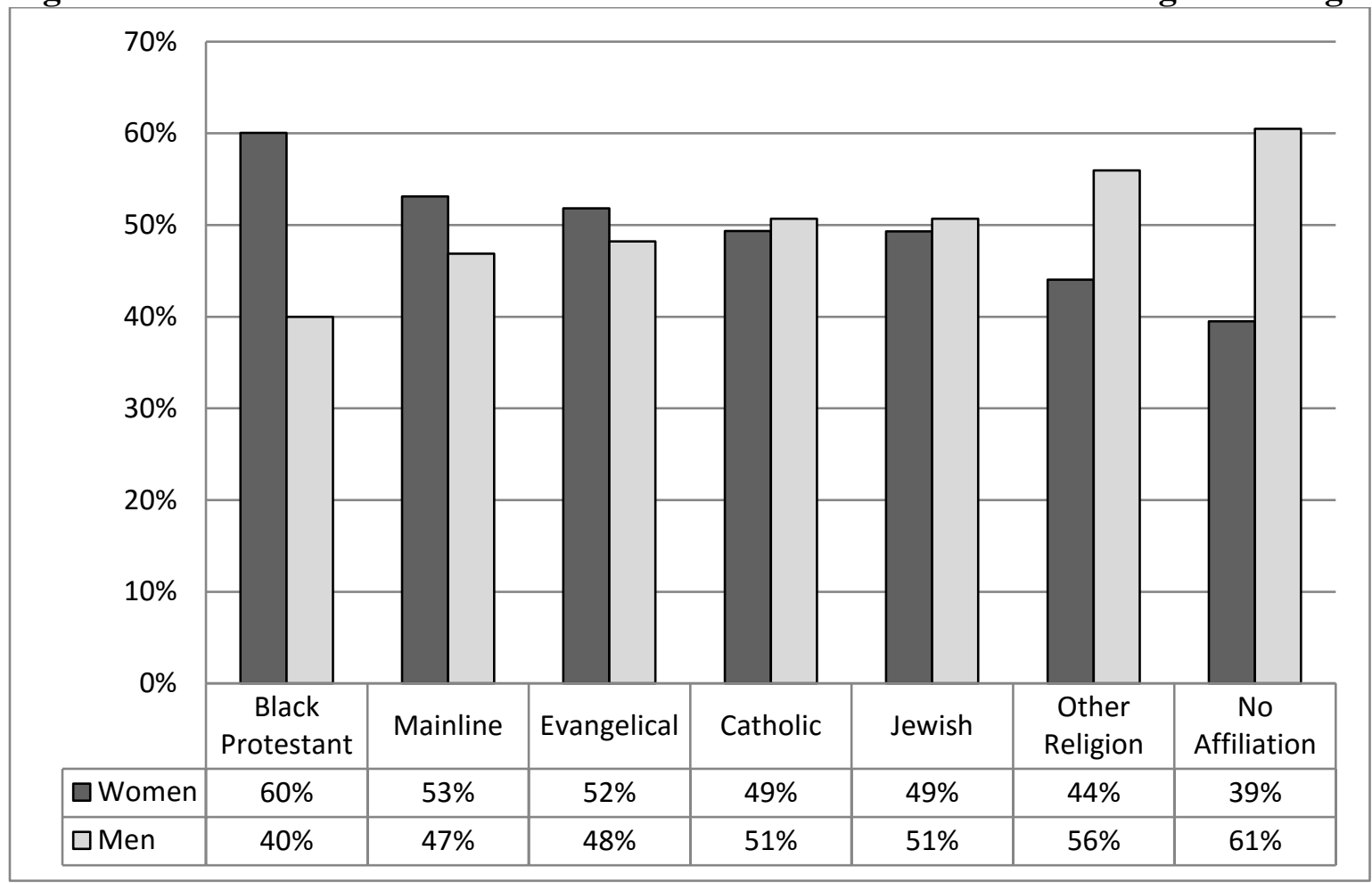

Source: General Social Survey, 1994-2012

Note: Cases were equalized by gender for comparison. 
Table 1: Predicted Probabilities of Gender Differences in Religiosity by Religious Category

\begin{tabular}{|c|c|c|c|c|}
\hline Measures & Women & Men & Women - Men & $\begin{array}{c}N \text { in } \\
\text { Category }\end{array}$ \\
\hline \multicolumn{5}{|l|}{ All Americans } \\
\hline Strong Affiliation ${ }^{\mathrm{a}}$ & .46 & .37 & $.09^{* * *}$ & 18,761 \\
\hline Weekly Attendance & .23 & .14 & $.09^{* * *}$ & 22,754 \\
\hline Daily Prayer & .70 & .42 & $.27^{* * *}$ & 14,447 \\
\hline Belief in Afterlife & .86 & .80 & $.06^{* * *}$ & 14,977 \\
\hline Belief in Literalism & .31 & .21 & $.10^{* * *}$ & 16,592 \\
\hline Belief in God, No Doubts & .71 & .52 & $.19^{* * *}$ & 10,584 \\
\hline Ever Had "Born Again" Experience & .38 & .28 & $.09^{* * *}$ & 9,675 \\
\hline Ever Tried to Proselytize & .46 & .34 & $.12^{* * *}$ & 8,617 \\
\hline \multicolumn{5}{|l|}{ Black Protestant } \\
\hline Strong Affiliation & .58 & .48 & $.09^{* * *}$ & 1,902 \\
\hline Weekly Attendance & .32 & .24 & $.09^{* * *}$ & 1,927 \\
\hline Daily Prayer & .86 & .73 & $.13^{* * *}$ & 1,203 \\
\hline Belief in Afterlife & .84 & .87 & -.02 & 1,281 \\
\hline Belief in Literalism & .67 & .53 & $.13^{* * *}$ & 1,418 \\
\hline Belief in God, No Doubts & .91 & .81 & $.10^{* * *}$ & 871 \\
\hline Ever Had "Born Again" Experience & .74 & .65 & $.09^{* *}$ & 781 \\
\hline Ever Tried to Proselytize & .78 & .72 & $.06^{+}$ & 706 \\
\hline \multicolumn{5}{|l|}{ Evangelical Protestant } \\
\hline Strong Affiliation & .52 & .45 & $.07^{* * *}$ & 5,962 \\
\hline Weekly Attendance & .38 & .28 & $.09^{* * *}$ & 6,133 \\
\hline Daily Prayer & .80 & .59 & $.22^{* * *}$ & 3,852 \\
\hline Belief in Afterlife & .90 & .88 & $.02^{+}$ & 4,175 \\
\hline Belief in Literalism & .54 & .46 & $.08^{* * * *}$ & 4,431 \\
\hline Belief in God, No Doubts & .83 & .74 & $.09^{* * *}$ & 2,223 \\
\hline Ever Had "Born Again" Experience & .71 & .64 & $.08^{* * *}$ & 2,653 \\
\hline Ever Tried to Proselytize & .74 & .66 & $.08^{* * *}$ & 2,323 \\
\hline \multicolumn{5}{|l|}{ Mainline Protestant } \\
\hline Strong Affiliation & .42 & .29 & $.13^{* * *}$ & 4,159 \\
\hline Weekly Attendance & .27 & .19 & $.08^{* * *}$ & 4,241 \\
\hline Daily Prayer & .70 & .44 & $.26^{* * *}$ & 2,653 \\
\hline Belief in Afterlife & .89 & .85 & $.04^{* *}$ & 2,791 \\
\hline Belief in Literalism & .26 & .22 & $.04^{* *}$ & 3,099 \\
\hline Belief in God, No Doubts & .70 & .52 & $.18^{* * *}$ & 1,921 \\
\hline Ever Had "Born Again" Experience & .37 & .35 & .03 & 1,662 \\
\hline Ever Tried to Proselytize & .46 & .39 & $.07^{* *}$ & 1,468 \\
\hline
\end{tabular}




\begin{tabular}{|c|c|c|c|c|}
\hline \multicolumn{5}{|l|}{ Catholic } \\
\hline Strong Affiliation & .37 & .30 & $.06^{* * *}$ & 5,734 \\
\hline Weekly Attendance & .29 & .21 & $.08^{* * *}$ & 5,765 \\
\hline Daily Prayer & .69 & .46 & $.24^{* * *}$ & 3,669 \\
\hline Belief in Afterlife & .85 & .81 & $.04^{* *}$ & 3,832 \\
\hline Belief in Literalism & .21 & .17 & $.04^{* * *}$ & 4,212 \\
\hline Belief in God, No Doubts & .71 & .57 & $.14^{* * * *}$ & 2,667 \\
\hline Ever Had "Born Again" Experience & .18 & .16 & .02 & 2,411 \\
\hline Ever Tried to Proselytize & .29 & .25 & $.04^{*}$ & 2,155 \\
\hline \multicolumn{5}{|l|}{ Jewish } \\
\hline Strong Affiliation & .38 & .43 & -.05 & 402 \\
\hline Weekly Attendance & .05 & .09 & $-.04^{\dagger}$ & 423 \\
\hline Daily Prayer & .39 & .22 & $.18^{* *}$ & 265 \\
\hline Belief in Afterlife & .63 & .50 & $.13^{*}$ & 260 \\
\hline Belief in Literalism & .05 & .11 & -.06 & 307 \\
\hline Belief in God, No Doubts & .30 & .25 & .05 & 185 \\
\hline Ever Had "Born Again" Experience & .03 & .04 & -.01 & 158 \\
\hline Ever Tried to Proselytize & .08 & .02 & $.06^{+}$ & 144 \\
\hline \multicolumn{5}{|l|}{ Other Religion } \\
\hline Strong Affiliation & .55 & .51 & .03 & 602 \\
\hline Weekly Attendance & .15 & .17 & -.02 & 726 \\
\hline Daily Prayer & .63 & .57 & .06 & 443 \\
\hline Belief in Afterlife & .86 & .81 & .05 & 472 \\
\hline Belief in Literalism & .14 & .13 & .01 & 508 \\
\hline Belief in God, No Doubts & .42 & .43 & -.01 & 312 \\
\hline Ever Had "Born Again" Experience & .18 & .15 & .03 & 270 \\
\hline Ever Tried to Proselytize & .18 & .14 & .04 & 247 \\
\hline \multicolumn{5}{|l|}{ No Religious Affiliation } \\
\hline Strong Affiliation & N/A & N/A & N/A & N/A \\
\hline Weekly Attendance & .02 & .01 & $.01^{\dagger}$ & 3,537 \\
\hline Daily Prayer & .29 & .14 & $.15^{* * *}$ & 2,362 \\
\hline Belief in Afterlife & .69 & .52 & $.17^{* * *}$ & 2,166 \\
\hline Belief in Literalism & .10 & .06 & $.04^{* * *}$ & 2,617 \\
\hline Belief in God, No Doubts & .26 & .16 & $.11^{* * *}$ & 1,778 \\
\hline Ever Had "Born Again" Experience & .12 & .09 & .03 & 1,740 \\
\hline Ever Tried to Proselytize & .17 & .14 & $.03^{+}$ & 1,574 \\
\hline
\end{tabular}

Source: General Social Survey 1994-2012

Note: Predicted probabilities based upon multivariate logistic regression models including all categories that control for year (dummies), age (continuous), race (dummies), region (dummies), residence population (dummies), marital status (binaries for currently married and ever divorced), parental status (binary for any children), education (dummies for highest degree attained), family income (continuous, inflation-adjusted to 2000 dollars), and work force status (dummies). All covariates are interacted with gender.

${ }^{a}$ Excludes those with no religious affiliation because it perfectly predicts the outcome (someone with no affiliation cannot be strongly affiliated).

${ }^{\dagger} p<0.10,{ }^{*} p<0.05,{ }^{* *} p<0.01,{ }^{* * *} p<0.001$ (two-tailed) 